\title{
Kesesuaian Rumus Schrool dan Pita Ukur Terhadap Bobot Badan Sapi Brahman Cross Di Kelompok Ternak Sumber Jaya Dusun Pilanggot Desa Wonokromo Kecamatan Tikung Kabupaten Lamongan
}

\section{Fitness Formula Schoorl and Tape Measure on Body Weight Brahman Cross in Animal Resources Group Dusun Pilanggot Desa Jaya District Wonokromo Tikung District Lamongan}

\author{
Moh. Romadhona Adi Susanto ${ }^{1}$, Ratna Kumala Dewi, S.Pt, MMG, M.Eng ${ }^{2}$, Ir. Mufid Dahlan, MMA ${ }^{3}$ \\ ${ }^{1}$ Mahasiswa Fakultas Peternakan \\ ${ }^{2}$ Dosen Pembimbing Utama \\ ${ }^{3}$ Dosen Pembimbing Pendamping \\ Program Studi Peternakan \\ Fakultas Peternakan, Universitas Islam Lamongan (UNISLA)
}

\section{RINGKASAN}

Usaha peternakan Sapi Brahman Cross (BX) hingga saat ini masih didominasi oleh peternakan rakyat dengan skala usaha kecil dan sistem pemeliharaannya bersifat tradisional. Sistem pemasaran Sapi di wilayah Kabupaten Lamongan masih menggunakan metode taksiran. Salah satu cara untuk memperkirakan bobot badan adalah dengan mengukur lingkar dada ternak karena lingkar dada seekor ternak memiliki korelasi yang sangat kuat untuk menduga bobot hidup ternak. Beberapa cara yang dapat digunakan untuk menentukan bobot hidup ternak adalah menggunakan rumus Schoorl dan pita ukur. Penelitian ini dilaksanakan di Kelompok Ternak Sumber Jaya Kecamatan Tikung Kabupaten Lamongan. Materi yang digunakan dalam penelitian ini adalah Sapi Brahman Cross (BX) sebanyak 30 ekor. Data hasil penelitian dianalisis menggunakan Uji-T. Hasil penelitian menunjukan bahwa nilai $\mathrm{T}$ hitung (t) antara rumus Schoorl dengan timbangan Digital lebih besar dari $\mathrm{T}$ tabel $\left(\mathrm{t}_{0,05}\right)$ yaitu $\left(t=76,26 \geq t_{0,05}=\right.$ $2,056)$, nilai $\mathrm{T}$ hitung $(\mathrm{t})$ antara pita ukur dengan timbangan Digital lebih besar dari $\mathrm{T}$ tabel $\left(\mathrm{t}_{0,05}\right)$ yaitu $\left(\mathrm{t}=52,5 \geq \mathrm{t}_{0,05}=2,056\right)$. Hasil tersebut menandakan bahwa terdapat penyimpangan yang signifikankan dalam pendugaan bobot badan Sapi Brahman Cross di Kelompok Ternak Sumber Jaya Kecamatan Tikung Kabupaten Lamongan.

\section{ABSTRACT}

Cattle breeding business Brahman Cross (BX) is still dominated by farm people with small scale and traditional maintenance system. Cattle marketing system in the district of Lamongan still using estimates. One way to estimate the body weight is to measure the circumference of the chest chest circumference of cattle because an animal has a strong correlation to estimate the live weight of cattle. Some of the ways that can be used to determine the live weight of cattle daalah using formulas Schoorl and the measuring tape. This research was conducted in group Livestock Sumber Jaya subdistrict Tikung Lamongan. The material used in this study is Brahman Cross Cattle (BX) as many as 30 individuals. The data were analyzed using T-test. The results showed that the count value $\mathrm{T}(\mathrm{t})$ between Schoorl formula with Digital scales larger than $\mathrm{T}$ table $(\mathrm{t} 0,05)$ ie $(\mathrm{t}=76.26 \geq \mathrm{t} 0,05=2.056)$, calculate the value of $\mathrm{T}(\mathrm{t})$ between the measuring tape with Digital scales larger than $\mathrm{T}$ table $(\mathrm{t} 0,05)$ ie $(\mathrm{t}=52.5 \geq \mathrm{t} 0,05=2.056)$. This result indicates that there are irregularities in the estimation of body weight signifikankan Brahman Cross Cattle in Group Tikung Livestock Sumber Jaya subdistrict in Lamongan district. Keywords : Body weight, measuring tape, schoorl formula, cow Brahman Cross (BX).

\section{PENDAHULUAN}

Usaha pemeliharaan sapi potong secara industry pada akhir-akhir ini semakin berkembang. Perkembangan industry sapi potong didorong oleh semakin meningkatnya permintaan daging dari tahun ketahun, sementara itu pemenuhan akan kebutuhan daging selalu kurang. Permintaan daging sapi pada tahun 2012 sebesar 484.000 ton diperkirakan kebutuhan daging dalam negeri tahun 2013 naik menjadi 550.000 ton (Rusman, 2012). Sapi Brahman Cross merupakan bangsa sapi yang mampu beradaptasi dengan cepat di Indonesia dan memiliki kecepatan pertambahan 
bobot badan serta memiliki bobot badan dasar yang tinggi (Williamson and Payne, 1993).

Bobot badan sapi merupakan salah satu indicator produktivias ternak yang dapat diduga berdasarkan ukuran linear tubuh sapi meliputi lingkar dada, panjang badan dan tinggi badan (Kadarsih, 2003). Peternak biasa menggunakan bobot badan hidup sapi sebagai keberhasilan pemeliharaan dan pertumbuhan sapi yang telah dipelihara apakah sesuai dengan harapan atau tidak. Pada bidang pemasaran bobot badan sapi sangat berpengaruh pada penentuan harga. Pertambahan bobot badan pada hewan menyebabkan hewan tersebut menjadi lebih besar dan diikuti dengan semakin menambah kekuatan dan kesuburan otot-otot penggantung Musculusserratus ventralis dan Musculuspectoralis yang terdapat didaerah dada,sehingga pada gilirannya ukuran lingkar dada semakin meningkat.

Masalah yang sering dihadapi dalam mengukur bobot badan ternak dalam jumlah yang besar serta biasanya tidak dikandangkan adalah membutuhkan peralatan, tenaga dan waktu yang banyak sehingga pekerjaan menjadi tidak efektif dan efisien.

Dalam usaha untuk mengatasi kendala yang dihadapi jika alat ukur untuk menduga bobot badan ternak yang berkapasitas besar tidak tersedia, dapat dilakukan penaksiran bobot badan ternak tersebut dengan menggunakan dimensi tubuhnya. Misalnya melalui panjang badan dan juga lingkar dada, Karena lingkar dada seekor ternak memiliki korelasi yang sangat kuat untuk menduga bobot hidup ternak (Parakkasi, 1999).

Pedagang sapi dan jagal yang sangat berpengalaman dapat menduga kemungkinan bobot karkas dari sapi hidup dengan ketetapan yang tinggi dengan melihat, tetapi kemampuan demikian tidak sama pada setiap pemilik ternak, kecuali para pemilik ternak mempunyai beberapa petunjuk. Perkiraan tentang bobot hidup adalah suatu tafsiran yang mungkin sangat jauh dari kenyataan (Williamson dan Payne, 1993). Salah satu metode yang dapat digunakan adalah dengan mengukur panjang badan dan lingkar dada. Terdapat beberapa rumus penduga bobot badan ternak menggunakan lingkar dada yaitu Schoorl, Winter, dan Denmark. Diantara rumus-rumus pendugaan bobot badan tersebut, rumus Schoorl diperkirakan sebagai rumus yang paling akurat terhadap bobot badan ternak sebenarnya. Rumus-rumus tersebut dapat digunakan untuk sapi, kambing, domba, babi, dan kerbau. Adapun langkah-langkah yang ditempuh dalam pengukuran badan ternak yang meliputi panjang badan adalah panjang dari titik bahu ketitik tulang (pin bone) dan lingkar dada diukur pada tulang rusuk paling depan persis pada belakang kaki depan.

Minish dan Fox (1979) menyatakan bahwa sapi Brahman di Australia secara komersial jarang dikembangkan secara murni dan banyak disilangkan dengan sapi HerefordShorthorn (HS). Hasil persilangan dengan Hereford dikenal dengan nama Brahman Cross (BX). Sapi ini mempunyai keistimewaan karena tahan terhadap suhu panas dan gigitan caplak, mampu beradaptasi terhadap makanan jelek serta mempunyai kecepatan pertumbuhan yang tinggi.Sapi Brahman mempunyai sifat pemalu dan cerdas serta dapat beradaptasi dengan lingkungannya yang bervariasi. Sapi ini suka menerima perlakuan halus dan dapat menjadi liar jika menerima perlakuan kasar. Konsekuensinya penanganan sapi ini harus hatihati. Tetapi secara keseluruhan sapi Brahman mudah dikendalikan.

Jumlah zat gizi yang dibutuhkan maupun kemampuan sapi dalam mengonsumsi bahan kering ransum didasarkan pada bobot badan sapi itu sendiri. Secara umum, bobot badan sapi dapat diketahui dengan melakukan penimbangan. Namun,pada umumnya para peternak tidak memiliki timbangan sapi karena harganya relative mahal. Oleh karena itu para peternak menggunakan alat ukur lainnya walaupun hasilnya tidak setepat timbangan sapi, yaitu pita ukur. Cara menggunakan alat ini adalah dengan mengukur lingkar dada sapi. Selanjutnya dengan menggunakan rumus, bobot badan sapi dapat diukur.

Penelitian-penelitian terhadap penggunaan pita ukur untuk menghitung bobot sapi sudah banyak dilakukan. Salah satu hasil penelitian yang masih relevan adalah penelitian yang telah dilakukan oleh Schoorl.

Berdasarkan pengalaman lapang, penggunaan rumus Schoorl lebih besar sekitar 1,5-32,6\% dari bobot badan sebenarnya (Sitorus, 1979). Namun, diantara rumus-rumus untuk 
memperkirakan bobot sapi, rumus Schoorl lebih mendekati kebenaran.

\section{METODE PENELITIAN}

Penelitian ini termasuk jenis metode penelitian kuantitatif yang komparatif karena telah memenuhi kaidah-kaidah ilmiah yaitu konkrit atau empiris, objektif, terukur, rasional dan sistematis.

Menurut Sugiyono (2013), metode kuantitatif dinamakan metode tradisional, karena metode ini sudah cukup lama digunakan sehingga sudah mentradisi sebagai metode untuk penelitian. Metode komparatif adalah metode penelitian yang membadingkan keberadaan satu variable atau lebih pada dua atau lebih sampel yang berbeda atau pada waktu yang berbeda.

Setelah data-data pengukuran tersebut diperoleh, selanjutnya dihitung bobot badan berdasakan metode pendugaan yang digunakan yaitu dengan rumus Schoorl. Menurut Gafar (2007), rumus yang dapat digunakan untuk menduga bobot badan adalah: RumusSchoorl:

$$
B B=\frac{(\mathrm{LD}(\mathrm{cm})+22)^{2}}{100}
$$

$$
\text { Dimana, } \quad \begin{array}{ll}
\mathrm{BB}=\text { Bobot Badan } \\
\mathrm{LD}=\text { Lingkar Dada }
\end{array}
$$

Pengambilan dan pengumpulan data sapi dilakukan dikelompok ternak Sumber Jaya, di Dusun Pilanggot, Desa Wonokromo, Kecamatan Tikung, Kabupaten Lamongan.

Data yang diambil sebanyak 30 ekor sapi Brahman Cross (BX). Sebelum dilakukan pengukuran lingkar dada terlebih dahulu mengamati umur ternak, selanjutnya bobot badan sapi tersebut. Bobot badan sapi ditimbang dengan menggunakan timbangan ternak digital great scale XK-3190A7 dengan kapasitas 3000 $\mathrm{kg}$ dan dengan tingkat ketelitian $1 \mathrm{~kg}$.

Data pengukuran tubuh. Pengukuran tubuh dilakukan saat sapi berdiri tegak pada bidang datar (posisi ternak "parallelogram").

Lingkar dada diukur dalam satuan $\mathrm{cm}$ yang diambil dengan cara mengikuti lingkaran dada atau tubuh tepat di belakang kaki depan ternak dengan menggunakan pita ukur. Data bobot badan diperoleh dengan cara menimbang sapi, dengan memasukan sapi ke dalam kandang jepit yang sudah dilengkapi dengan timbangan ternak. Penafsiran umur ditentukan dengan mengamati pergantian gigi seri susu menjadi gigi seri permanen. Caranya setelah tubuh sapi diukur, mulut sapi dibuka lalu diamati pergantian gigi dan jika ternak sudah cukup tua dan giginya sudah permanen semua maka diamati beberapa bidang asalnya.

\section{VARIABEL PENGAMATAN}

Variabel yang digunakan dalam penelitian ini yaitu Rumus Schoorl, Pita Ukur, bobot badan sapi Brahman Cross (BX).

\section{ANALISIS DATA}

Data yang digunakan dalam penelitian ini dapat dikelompokan menjadi 2, antara lain yaitu :

\section{a. Data Primer}

Data primer merupakan data utama yang pengambilanya dilakukan secara langsung. Data primer ini diperoleh dari pengukuran terhadap 30 ekor sapi dikelompok ternak Sumber Jaya, di Dusun Pilanggot, Desa Wonokromo, Kecamatan Tikung, Kabupaten Lamongan.

Data Sekunder

Dalam rangka pembuktian hipotesis, maka dalam penelitian ini menggunakan analisis $\mathrm{Uji} T$ untuk masing-masing metode pengukuran.

Menurut Akbar (2008) besarnya nilai penyimpangan dihitung menggunakan rumus sebagai berikut :

$P=\frac{B B R-B B T}{B B T} \times 100 \%$

Keterangan:

$\mathrm{P} \quad=$ Prosentase Penyimpangan

$\mathrm{BBR}=$ Bobot Badan Rondo

BBT = Bobot Badan Timbangan

Untuk mencari besarnya nilai perbedaan

antara penggunaan pita ukur Rondo dan timbangan Digital menggunakan Analisis Uji T. Menurut Hadi (1996). Rumus Uji T adalah sebagai berikut :

$$
t=\frac{\left[M_{x}-M_{y}\right]}{\sqrt{\frac{\sum b^{2}}{N(N-1)}}}
$$

Keterangan:

$$
\begin{array}{ll}
\mathrm{M}_{\mathrm{x}} \text { dan } \mathrm{M}_{\mathrm{y}} & =\text { Mean dari sampel } \mathrm{x} \text { dan sampel } \\
\Sigma \mathrm{b}^{2} & \mathrm{y} \\
& =\text { jumlah deviasi dari mean } \\
\mathrm{N} & \text { perbedaan } \\
& =\text { Jumlah sampel/ subyek }
\end{array}
$$




\section{HASIL DAN PEMBAHASAN}

\section{Hasil Pengukuran Lingkar Dada dan Bobot Badan Sapi Brahman Cross (BX).}

Ukuran-ukuran linear tubuh merupakan suatu ukuran dari bagian tubuh ternak yang pertambahannya satu sama lain saling berhubungan secara linear, Kadarsih (2003) menyatakan bahwa ukuran linear tubuh yang dapat dipakai dalam memprediksi produktivitas sapi antara lain panjang badan, tinggi badan, lingkar dada.

Dalam penelitian ini jumlah sapi yang akan diteliti sebanyak 30 ekor sapi Brahman Cross (BX). Dibawah ini disajikan nilai rata rata lingkar dada dan bobot badan sapi Brahman Cross (BX).

Tabel 4.1 Data Lingkar Dada dan Bobot Badan Sapi Brahman Cross (BX).

\begin{tabular}{|c|c|c|c|}
\hline & Umur & $\begin{array}{c}\text { Lingkar } \\
\text { dada }\end{array}$ & $\begin{array}{c}\text { Bobot } \\
\text { badan }\end{array}$ \\
\hline Jumlah & $\begin{array}{c}652 \\
\text { bulan }\end{array}$ & 4692 & 8776 \\
\hline $\begin{array}{c}\text { Rata - } \\
\text { rata }\end{array}$ & $\begin{array}{c}21,73 \\
\text { bulan }\end{array}$ & 156,4 & 292,53 \\
\hline
\end{tabular}

Sumber : data primerdiolah (2016)

Dari pengukuran lingkar dada dan bobot badan pada sapi Brahman Cross (BX) di Kelompok Ternak Sumber Jaya yang bertempat di KecamatanTikung Kabupaten Lamongan yang lebih lengkap dapat dilihat pada Lampiran 1 .

Berdasarkan Tabel 4.1 diketahui bahwa sapi - sapi Brahman Cross (BX) yang digunakan oleh peneliti adalah sapi yang masih muda atau masih berumur kurang dari 2 tahun, yang memiliki rata - rata lingkar dada $156,4 \mathrm{~cm}$ dan bobot badan rata - rata $292,53 \mathrm{~kg}$.

Pada umur - umur muda pertumbuhan berlangsung lebih cepat dibandingkan dewasa bahkan pada umur dewasa pertumbuhan relative konstan. Pertumbuhan paling cepat pada waktu pedet lahir sampai umur 2 tahun kemudian 2 sampai 4 tahun, kecepatan pertumbuhan mulai berkurang setelah 4 tahun pertumbuhan mulaitetap (Pane, 1993).

Pemeliharaan sapi potong untuk penggemukan dapat dilakukan dengan menggunakan system pemeliharaan intensif, semi intensif dan ekstensif. Phillips (2001) menjelaskan bahwa system pemeliharaan intensif merupakan system dimana sapi dipelihara dalam kandang dengan pemberian pakan konsentrat berprotein tinggi dan juga dapat ditambah dengan memberikan hijauan. Sistem pemeliharaan semi intensif adalah sapi selain dikandangkan juga digembalakan dipadang rumput, sedangkan system ekstensif pemeliharaannya di padang penggembalaan dengan pemberian peneduh untuk istirahat sapi.

\section{Uji-T Hasil Pendugaan Bobot Badan Sapi Brahman Cross (BX)Antara Rumus Shoorl Dengan Timbangan Digital.}

Penelitian-penelitian terhadap penggunaan pita ukur untuk menghitung bobot sapi sudah banyak dilakukan. Salah satu hasil penelitian yang masih relevan adalah penelitian yang telah dilakukan oleh Schoorl (Suwarno, 1958). Sapi yang diukur dengan menggunakan rumus Schoorl adalah sapi dewasa, sedangkan untuk pedet rumus ini kurang tepat, karena factor penambahan 22 untuk lingkar dada pada sapi yang sedang tumbuh terlalu besar.

Tabel 4.2Uji-T Hasil Pendugaan Bobot Badan Sapi Brahman Cross (BX) antara Rumus Shoorl Dengan Timbangan Digital.

\begin{tabular}{|l|l|l|l|l|l|}
\hline & $\begin{array}{l}\text { Schoor } \\
1 \\
(\mathrm{x})\end{array}$ & $\begin{array}{l}\text { T.Digit } \\
\text { al } \\
(\mathrm{y})\end{array}$ & $\mathrm{b}^{2}$ & \multicolumn{1}{c|}{$\begin{array}{l}\mathrm{T} \text { hitung } \\
=\frac{\left[M_{y}-M_{z}\right.}{\sqrt{\frac{\Sigma b^{2}}{N(N-1}}}\end{array}$} & $\begin{array}{l}\text { T table } \\
\left(\mathrm{T}_{0.05 \mathrm{df} 26}\right)\end{array}$ \\
\hline $\begin{array}{l}\text { Jumla } \\
\text { h }\end{array}$ & 9554 & 8776 & $\begin{array}{l}105, \\
47\end{array}$ & 76,26 & 2,056 \\
\hline
\end{tabular}

Sumber : data primerdiolah (2016)

Berdasarkan Tabel 4.2 diatas diketahui bahwa nilai $\mathrm{T}$ hitung( $\mathrm{t}$ ) lebih besar disbanding dengan nilai $\mathrm{T}$ tabel $\left(\mathrm{t}_{0,05}\right)$ sebesar $(\mathrm{t}=76,26 \geq$ $\mathrm{t}_{0,05}=2,056$ ) yang artinya tolak $\mathrm{H}_{0}$ dan terima $\mathrm{H}_{1}$. 
Hal ini menunjukkan adanya perbedaan yang signifikan dengan hasil perhitungan rumus Schoorl terhadap bobot badan sebenarnya. Besarnya nilai penyimpangan tersebut selaras dengan yang dikemukakan (Sitorus, 1979) bahwa hasil rumus Schoorl lebih besar sekitar 1,5-32,6\% dari bobot badan sebenarnya.

Kandungan nutrisi dan komposisi kimia bahan pakan yang masuk saluran pencernaan merupakan factor utama yang mempengaruhi pertumbuhan (Soeparno, 1994). Kekurangan pakan merupakan kendala besar dalam proses pertumbuhan. Terlebih apabila dalam pakan tersebut banyak zat-zat pakan untuk pertumbuhan tersedia sangat kurang seperti protein, mineral dan vitamin (Sugeng, 2003).

Dalam pemberian pakan harus dilakukan secara kontinyu sepanjang waktu. Pemberian pakan yang tidak kontinyu akan menimbulkan perubahan terhadap sapi-sapi yang dipelihara di daerah tropis, termasuk di Indonesia. Pertumbuhan sapi-sapi yang dipelihara di daerah tropis sering mengalami kurva naik turun yang sangat tajam. Pertumbuhan dan pertambahan berat badannya sangat cepat ketika pada musim penghujan, karena mendapat makanan yang cukup, sedangkan pada musim kemarau pertumbuhan dan berat badannya sangat menurun secara drastis. Selama musim kemarau daya cerna hijauan berkurang. Hal ini disebabkan oleh hilangnya energy, mineral dan protein yang terkandung dalam hijauan akibat kekurangan air. Hijauan yang diberikan kepada ternak menjadi tidak memenuhi syarat, bahkan volume pemberiannya seringkali sangat berkurang. Akibatnya adalah pertumbuhannya terhambat, sapi yang sudah dewasa berat badannya dapat menurun atau kurus, perkembangbiakannya mundur karena fertilitasnya ikut menurun, prosentase karkasnya sangat rendah (Sugeng, 2003).

\section{Uji-T Hasil Pendugaan Bobot Badan Sapi Brahman Cross (BX)Antara Pita Ukur Dengan Timbangan Digital.}

Secara umum, bobot badan sapi dapat diketahui dengan melakukan penimbangan. Namun bisa juga menggunakan alat pengukur lainnya walaupun hasilnya tidak setepat timbangan sapi, yaitu pita ukur. Cara menggunakan alat ini adalah dengan mengukur lingkar dada sapi. Selanjutnya dengan menggunakan rumus, bobot badan sapi dapat diukur (Santoso, 2003).

Tabel 4.3Uji-T Hasil Pendugaan Bobot Badan Sapi Brahman Cross (BX) antara Pita Ukur Dengan Timbangan Digital.

\begin{tabular}{|c|c|c|c|c|c|}
\hline 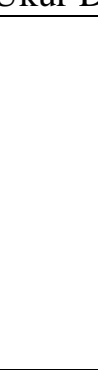 & $\begin{array}{l}\text { Pit } \\
\text { a } \\
\text { uk } \\
\text { ur } \\
\text { (x) }\end{array}$ & $\begin{array}{c}\text { T.Dig } \\
\text { ital } \\
(y)\end{array}$ & $b^{2}$ & $\begin{array}{l}\text { T hitung } \\
t \\
=\frac{\left[M_{y}-M\right.}{\sqrt{\frac{\sum b^{2}}{N(N-}}}\end{array}$ & $\begin{array}{c}\mathrm{T} \\
\text { tabl } \\
\mathrm{e} \\
\left(\mathrm{T}_{0.0}\right. \\
5 \mathrm{df} \\
26)\end{array}$ \\
\hline $\begin{array}{c}\text { Juml } \\
\text { ah }\end{array}$ & $\begin{array}{l}94 \\
06\end{array}$ & 8776 & $\begin{array}{c}147 \\
86\end{array}$ & 52,5 & $\begin{array}{c}2,05 \\
6\end{array}$ \\
\hline
\end{tabular}

Sumber : data primer diolah (2016).

BerdasarkanTabel 4.3 di atas diketahui bahwa nilai $\mathrm{T}$ hitung( $\mathrm{t}$ ) lebih besar disbanding dengan nilai $\mathrm{T}$ tabel $\left(\mathrm{t}_{0,05}\right)$ sebesar $(\mathrm{t}=76,26 \geq$ $\mathrm{t}_{0,05}=2,056$ ) yang artinya tolak $\mathrm{H}_{0}$ dan terima $\mathrm{H}_{1}$.

Hal ini menunjukkan perbedaan yang signifikan dengan hasil perhitungan Pita ukur terhadap bobot badan sebenarnya. Ketidak cocokan bobot yang sebenarnya dengan bobot hidup pita ukur pada sapi - sapi Indonesia telah dilaporkan oleh Wachyudar yang diacu dalam (Suardi, 1993). Menurut yang bersangkutan pendugaan bobot hidup dengan pita ukur menghasilkan bobot hidup yang sangat nyata lebih tinggi dari bobot yang sebenarnya.

Skor kondisi tubuh merupakan suatu system penilaian secara umum yang telah dikembangkan untuk mendugarataan kondisi sapi dalam suatu pemeliharaan merupakan definisi skor kondisi tubuh. Menurut Encinias dan Lardy (2000), skor kondisi tubuh merupakan metode penilaian secara visual yang mempertimbangkan frame size atau bentuk tubuh (Phillips, 2001).

\section{KESIMPULAN DAN SARAN \\ 1. Kesimpulan \\ Berdasarkan penelitian yang telah selesai dilakukan diketahui bahwa terdapat penyimpangan pendugaan bobot badan yang signifikan antara penggunaan rumus Schoorl}


dengan Timbangan Digital di Kelompok Ternak Sumber Jaya Kecamatan Tikung Kabupaten Lamongan, dengan diketahui bahwa nilai $\mathrm{T}$ hitung $(\mathrm{t})$ lebih besar dibanding dengan nilai $\mathrm{T}$ tabel $\left(\mathrm{t}_{0,05}\right)$ yaitu $=\left(\mathrm{t}=76,26 \geq \mathrm{t}_{0}=2,056\right)$ yang artinya tolak $\mathrm{H}_{0}$ dan terima $\mathrm{H}_{1}$. Penyimpangan pendugaan bobot badan yang signifikan juga terdapat antara penggunaan Pita Ukur dengan Timbangan Digital dengan diketahui bahwa nilai $\mathrm{T}$ hitung $(\mathrm{t})$ lebih besar dibanding dengan nilai $\mathrm{T}$ tabel $\left(\mathrm{t}_{0,05}\right)$ yaitu $=\left(\mathrm{t}=52,5 \geq \mathrm{t}_{0}=2,056\right)$ yang artinya tolak $\mathrm{H}_{0}$ dan terima $\mathrm{H}_{1}$. Jadi pengukuran yang lebih mendekati dengan bobot badan sesungguhnya adalah dengan menggunakan Pita Ukur.

\section{Saran}

Untuk penelitian selanjutanya disarankan untuk menggunakan jenis sapi selain sapi Brahman Cross (BX) dan dapat pula membedakan jenis kelaminnya supaya bisa dibandingkan dengan penelitian sebelumnya.

\section{DAFTAR PUSTAKA}

Akbar, Muhammad. 2008. Pendugaan Bobot Badan Sapi Persilangan Limousin berdasarkan Panjang Badan dan Lingkar Dada. Fakultas Peternakan. Universitas Brawijaya. Malang.

Basya, S. 2009. Penggemukan Sapi. Penebar Swadaya, Jakarta.

Blakely J, Bade DH. 1992. Ilmu Peternakan. Edisi Ke-empat. Terjemahan B.Srigandono. UGM Press, Yogyakarta.

Blakely J. David H.D. 1994. Ilmu Peternakan. Gajah Mada University Press, Yogyakarta.

Encinias, A. M. and G. Lardy. 2000. Body condition scoring I: managing your cow herd through body condition scoring. Ext. Publ. AS-1026. North Dakota State University.

Fivet Animal Health.Rondo Tape Measure. Zimbabwe. (diakses pada tanggal 10 Agustus 2016).

Gunawan, Abubakar, G.T. Prambudi, D. Nista, A. Purwadi, K. Karim, A. Karnaen, W. Ediyati, P. Djajadiredja, dan P.P. Putro. 2008. Petunjuk Pemeliharaan Sapi Brahman Cross. BPTU Sapi Dwiguna dan Ayam Sembawa.
Direktorat Jenderal Peternakan, Departemen Pertanian.

Gafar, S. 2007. Memilih dan memilah hewan qurban.

Hadi, Sutrisno.1996. Statistik cetakan keenam belas jilid dua. Andi Offset. Yogyakarta.

Hassen, A., D.E Wilson, G.H Rouse and R.G Tait. 2004. Use of Linear and Non Linear Growth Curves to Describe Body Weight Changes of Young Angus and Heifers. Iowa State University Animal Industry Report. A.S Leaflet R1869.Kadarsih, S. 2003. Peranan Ukuran Tubuh Terhadap BadanSapi Bali di Provinsi Bengkulu. J. penelitian UNIB. 9 (1): 45-48.

Kadarsih, S. 2003. Peranan Ukuran Tubuh Terhadap BadanSapi Bali di Provinsi Bengkulu. J. penelitian UNIB. 9 (1): 45-48.Minish, G. L. and D. G. Fox, 1979. Beef Production and Management. Reston

Publishing Co., Inc. A Prentice-Hall Co., Reston, Virginia.

Minish, G.1. andD.G.Fox, 1979. Beef Production and Management. Reston Publishing Co. Inc. A Prentice Hall Co. Reston. Virginia.

Murtidjo, B.A. 1992. Beternak Sapi Potong. Kanisius, Yogyakarta.

Murtidjo, B.A. 1993. Beternak Sapi Potong. Kanisius, Yogyakarta.

Nasir, M. 1998. Metode Penelitian, Ghalia Indonesia. Jakarta.

Pane, I. 1993. Pemuliabiakan Ternak Sapi. PT Gramedia Pustaka Utama, Jakarta.

Parakkasi, A. 1999. Ilmu Nutrisi dan Makanan Ternak Ruminansia. Universitas press, Jakarta.

Phillips, C.J.C. 2001. Pinciples of Cattle Production. CABI Publishing. London.

Purnomoadi, Agung. 2003. Ilmu Ternak Potong dan Kerja. UniversitasDiponegoro, Semarang.

Rusman. 2012. Kebutuhan Sapi Potong di Indonesia tahun 2013. Wakil menteri pertanian Republik Indonesia.

Santoso, U. 2003. Tatalaksana Pemeliharaan Sapi. Cetakan Ke-empat. Penebar Swadaya, Jakarta. 
Sitorus, S. 1979. Ketepatan Pemakaian Pita Ukur pada Penentuan Bobot Badan Sapi Potong Peranakan Ongole di Pasar Ternak Plaosan, Magetan. Lembaran LPP No. 3 halaman 1-4. Bogor.

Soeparno. 1994. Ilmu dan Teknologi Daging. Cetak Ke-dua. Gajah Mada University press, Yogyakarta.

Suardi, 1993. Hubungan bobot hidup yang sebenarnya denga nbobot hidup yang diduga dengan pita ukur pada sapi local. Skripsi. Fakultas Peternakan Universitas Andalas. Padang.

Sugeng, B. 2002. Sapi Potong. Penebar Swadaya, Jakarta.

Sugeng, B. Y. 2003. Sapi Potong. Penebar Swadaya, Jakarta.

Sugiyono. 2013. Metode Penelitian Kuantitatif Kualitatif dan R\&D. Alfabeta, Bandung.

Supriyono. 1998. Ilmu Ternak. Fakultas Peternakan. Universitas Gajah Mada, Yogyakarta.

Suwarno, R. 1958. Mempraktekan Pelajaran Pertumbuhan pada Hewan Relasi antara Lingkar Dada, Panjang Badan dan Berat Badan. HameraZoa, Archipel, Bogor.

Turner, H.N. 1981. Animal genetic resources. Int. Goat and Sheep Res. 1(4):243.

Williamson, G. dan W.J.A. Payne, 1978. An Introduction to Animal Husbandry in The Tropics, Second Edition, ELBS and Longman Group Limited, London.

Williamson G., and W.J.A. Payne, 1993. Pengantar Peternakan di Daerah Tropis, Cetakan Pertama, Diterjemahkan SGN. Djiwa Darmadja. Gajah Mada University Press, Yogyakarta.

Yusuf, M. 2004. Hubungan Antara Ukuran Tubuh Dengan Bobot Badan Sapi Bali di Daerah Bima NTB. Skripsi Fakultas Peternakan Gadjah Mada, Yogyakarta. 